PRODUCTION

ENGINEERING ARCHIVES
2016, Vol. 13, No. 4, pp 31-34

ISSN 2353-5156 (print version)

ISSN 2353-7779 (online version)

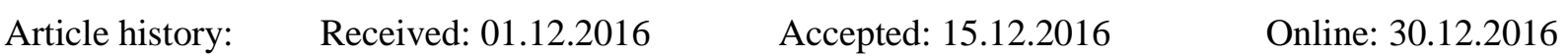

\title{
Methods of measuring the effectiveness of Lean Management
}

\begin{abstract}
Marcel Lizak ${ }^{1}$
${ }^{1} \mathrm{PhD}$ student, Czestochowa University of Technology, Faculty of Management, Armii Krajowej 19B, 42-200 Częstochowa, Poland, +48 669214 137, e-mail: marcellizak876@gmail.com

Abstract. Invalid organisation of the production environment in an enterprise is the cause of many disruptions during the implementation of production processes. Lean Management is aimed at improving processes and eliminating interference in accordance with the Kaizen principle. A significant element of management constantly analyses and measures the improved results. The article presents the results of the literature research from the scope of observation methods and measuring the effects of the use of Lean Management instruments in manufacturing companies.
\end{abstract}

Key words - Lean Management, production efficiency, Kaizen

\section{The origin of Lean Management}

Lean Management belongs to the family of modern management concepts. It is used in many diverse sectors of the global economy. It has been observed that more and more implementation ways of Lean Management concept resulted in success.

A diverse terminology in accordance with the concept of lean management can be found in literature. Lean is formulated as a slender approach that "[...] shows the way of producing more volume using less minimising human labour, reducing the number of devices, as well as saving time and space - all at increased level of meeting the customers' needs [...] it also allows to achieve a greater level of job satisfaction [...]" (WOMACK J. P., Jones D. T. 2012). Liker explains the issue of "lean management" as an aspiration to efficiently manage the resources, and as a result of that to reduce expenses, quality orientation and minimising the waiting time of implementation of orders (LIKER J. K. 2005). Lean Management is defined as a set of concepts, principles, procedures and tools adapted to improve of the production process by reducing waste (TAJ S. 2008).

Lean is sometimes referred to as a system of waste elimination, or cost reduction. These terms are too simplistic, therefore, they do not show the essence of the system built up over the decades (since around 1950) at Toyota. It is also sometimes mistakenly associated by Polish workers with only audits controlling keeping an order of work stations, drawing lines in the production hall and the ubiquitous hanging instructions and symbols, or measuring work time and increasing standards. Wrong picture about Lean is often a result of inadequate management attitude (MASSAKI I. 2006). It is often the cause of the unfortunate use of financial measures to assess the effectiveness of lean tools.

The need for continuous improvement of the company derived from the Toyota Production System re- 
quired elaboration certain methods (5S, PDCA, Andon, standardized work, define the main waste in the company, etc.), which helped to improve processes. These methods are often referred to just as Lean tools. Kaizen, that is continuous improvement, should be treated as a foundation of Lean Management, without which the company will only have randomly selected elements of lean management (ULEWICZ R., KUCĘBA R. 2016). Saakichi Toyoda introduced the first pillar of the Structure of Toyota Production House (WOMACK J. P., Jones D. T., Roos D. 2008). It is based on respect in relations to other people and self-improvement of skills. The main elements in this scheme are stability, $5 \mathrm{~S}$ rule, reduction of volatility and limitation of production machines breakdowns. Jidoka relied on the quality built-in work station. Whereas Kichiro, who visited Ford factory in the USA, implemented mass production and the second pillar of which was the principle of just in time - speaking about delivery timeliness. The purpose of this system was to reduce the cost but keep an appropriate level of quality, minimizing products delivery time by limiting waste during the operation of production processes (OHNO T. 2008). At the same time the leader was appointed what has became the Toyota Motor Production. This phenomenon was called Lean Manufacturing. Simultaneously, the authors of Lean Thinking have extended the approach beyond the motor industry to business processes (MANN D. 2014).

\section{Instruments of Lean Management}

Lean Management has instruments which by functioning improve implementation of modern management concepts. The presented tools are implemented in companies that are at a similar level. As a rule, after a year of progress with the Lean Management project they are at $80 \%$ in Poland and Mexico (BEDNAREK M., 2015):

- $5 \mathrm{~S}$,

- TPM,

- SMED.

During the implementation of $5 \mathrm{~S}$ practices the human factor should be taken into account. This method has become a recovery plan, by affecting the company financial result has become a way of action. At the same time the relationship between the employ- ees and the organisation they work in every day has been taken care of. The first element was the training of the management team, who should adapt to the new working conditions by using innovative organizational techniques. Workshops include planning tasks and tight control of the progress that employees performed on every work station. It the use of the implementation of a cyclic system results review was also scrutinized. Each unit in an organization should identify with the organizational aim with particular emphasis on quality, work efficiency, cost reduction, delivery on time, safety of staff and product, clean and tidy workplace, reduce wastage (CZERSKA J. 2014).

Total Productive Maintenance this is all company's activities, which purpose is to prevent errors of qualitative nature of the products, the occurrence of equipment failure and the condition required in terms of frequent adjustment (BORKOWSKI S., UlEWICZ R. 2009). The purpose of the TPM is to accelerate the work of machine operators. At the same time focusing on work safety and ease of operation. The assumption of the overriding aim of TPM is a zero failures, zero defects arising during machine operation. Referring to the elementary principles of Lean is to minimize waste and improve the level of improvement of the organization, so the purpose of TPM, one of the pillars of Lean is also to minimize losses. Presented below are 6 great losses (CZERSKA J. 2014):

- Failure of equipment.

- Set-up and establishment of workstations.

- Short Term downtime during operation.

- Loss of speed.

- Defects in the quality and a need to correct defective parts.

- Low material utilization and losses at start-up of the machine.

Then listed the five elements of TPM (KUNIO S. 1992):

- Improvements to eliminate the causes of 6 big losses.

- Antonomous maintenance.

- Scheduled system maintenance.

- Training.

- Purchasing and design reliable and easy to maintenance equipment.

The SMED (Single Minute Exchange of Die), an one digit exchange form. The technique of performing 
of retooling of machines and devices in less than 10 minutes was formulated. Retooling is defined as the time measured from the last good product produced on the old machine setting to the first good product produced on a new setting of the machine, which should start a mass production (SHINGO S. 1985).

\section{Measurements and metrics of Lean Management}

The message of Lean is to avoid any kind of waste, reducing the internal functions of a company to what is necessary, and in relation to the manufacturing process, eliminating steps not adding value to a product. Unnecessary actions lengthen production time and often are results of an organizational mess, causing an additional low quality production. According to the principles of Lean Management company should be reorganized so that customers orders were carried out in the shortest possible time and with minimal employees effort. This also allows shortening production cycles, improving product quality, reducing production costs, improving morale and commitment of staff. In literature you can meet with different types of measures used in Lean Management. A common feature of these measures is defined aim and measurable parameters that define it. An important element is the designation of measurements that are needed and feasible to implement. In an interview for the Lean Enterprise Institute Poland Orest Company - Chief Financial Officer WIREMOLD, warns against using financial measures.

In a production company, that only begin to implement Lean, the financial results of the first two years almost always deteriorate. A more beneficial is to use metrics related to time and exactly the ratio of release time, which was consumed for operations not giving added value. The meter associated with the release of additional production capacity in the company can also be used.

Productivity is also often used to define the effects of lean management. Productivity is the ratio of the result or effect of which is achieved by certain process, to the resources consumed to achieve this effect. By resources the following is meant: materials, human labour and the individual elements of the overall costs.
On the list of measures in the literature (ULEWICZ R., MAZUR M. 2015) can be found inter alia:

- inventory turnover ratio,

- reduction of shortages,

- reduction of retooling time,

- reduced manufacturing costs

- lead time,

- cycle time,

- reduction of overtime,

- reduction of waste,

- increasing the number of sales of products,

- increase the efficiency of use of the new fund crush-time work,

- increasing the efficiency of machinery and equipment,

- freeing resources - time, effort and materials

- stabilize and standardize processes (re-flow materials, line work, line balancing),

- levelling of production, the organization of the assembly work station/production,

- improving health and safety.

Data for indicators should come from automated records or forms filled by operators. The choice of measures should depend on what a company wants to achieve and on type of Lean tools, which is implemented in a company. Do not use all measures at once. When introducing Lean tools the metrics should be chosen to most accurately assess the effect of changes resulting from the new tool (eg. 5S, Kazien, Just in Time, Kanban, VSM, TPM collocation of equipment, etc.).

\section{Summary}

The concept of Lean is aimed at improving and increasing the efficiency of operating processes in an enterprise. The assessment of activities included in the process because of their desirability and usefulness should be done during its implementation. The motto of the introduction of Lean could be a statement of P. Drucker: There is nothing quite so useless as doing with great efficiency, something that should not be done at all.

A question why to measure and analyse efficiency of inefficient things may further be posed.

A common mistake when performing measurements to determine the metrix is complicated analysis 
and the time needed to carry it out, which can be wasteful in itself.

Every company wants to do the best to achieve the purposes, and strive to fulfil the company's vision. A company should set as well as to measure key performance indicators. The key performance indicators are important part of the assessment of the organization, as they allow clearly decide whether their aims are all implemented and at what stage they are at. When a company does not implement the set targets, you can quickly counteract it, find the problem and then find a solution. Incredible advantage given by the use of efficiency measures is that they influence the organizational culture very well, which prevails in a company, and their use contributes to the fact that employees know exactly what is expected of them and what the rules of assessing their work are.

\section{Literature}

1. BEDNAREK M. 2015. Zastosowanie Lean Manufacturing $w$ Polsce i Meksyku. Modele-praktyka-doświadczenia. Difin, Warszawa.

2. BORKOWSKI S., ULEWICZ R. 2009. Instrumenty doskonalenia procesów produkcyjnych. Instruments of Production Processes Improvement. PTM, Warszawa.

3. Czerska J. 2014. Podstawowe Narzędzia Lean Manufacturing. Lean Manufacturing Basic Toolbox. LeanQ Team, Gdańsk.

4. CZERSKA J. 2014. Doskonalenie strumienia wartości. LeanQ Team, Gdańsk.

5. FORD H. 2007. Dziś i jutro. ProdPublishing.com, Wrocław.

6. KUNIO S. 1992. TPM for supervisors. Productivity Press, Portland.

7. LIKER J. K. 2005. Droga Toyoty. 14 zasad zarządzania wiodacej firmy produkcyjnej świata. Wyniki badań BOST. MT Biznes, Warszawa.

8. MANN D. 2014. Tworzenie kultury Lean. Wydawnictwo ProdPublishing.com, Wrocław.

9. MASSAKI I. 2006. Gemba kaizen. Zdroworozsadkowe, niskokosztowe podejście do zarządzania. MT Biznes, Warszawa.

10. OHno T. 2008. System Produkcyjny Toyoty. Więcej niż produkcja na duża skalę. ProdPublishing.com, Wrocław.
11. SHINGO S. 1985. A revolution in manufacturing: the SMED system. Productivity Press, New York.

12. TAJ S. 2008. Lean manufacturing performance in China: assessment of 65 manufacturing plants. J. Manuf. Technol. Manag., 19, pp. 217-234.

13. UlewiCZ R., KuCĘBA R. 2016. Identification of Problems of Implementation of Lean Concept in the SME Sector. Economics and Management nr8, pp.19-25.

14. UlewiCZ R., MAZUR R. 2015. Doskonalenie transportu wewnętrznego z wykorzystaniem koncepcji Lean-Studium przypadku. Przegląd Organizacji nr 7, pp. 6-13.

15. Womack J. P., Jones D. T. 2012. Lean Thinkingszczupłe myślenie. Eliminowanie marnotrawstwa $i$ tworzenie wartości $w$ przedsiębiorstwie. Wydawnictwo ProdPublishing.com, Wrocław.

16. Womack J. P., Jones D. T., Roos D. 2008. Maszyna, która zmieniła świat. Wydawnictwo ProdPublishing.com, Wrocław. 